\title{
A model of seasonal foliage dynamics of the subtropical mangrove species Rhizophora stylosa Griff. growing at the northern limit of its distribution
}

Sahadev Sharma ${ }^{1,2^{*}}$, A T M Rafiqul Hoque ${ }^{1,2,3}$, Kangkuso Analuddin $^{4}$ and Akio Hagihara ${ }^{5}$

\begin{abstract}
Background: Progress of forest production in response to the environment requires a quantitative understanding of leaf area development. Therefore, it is necessary to investigate the dynamics of seasonal crown foliage in order to understand the productivity of mangroves, which play an important role in the subtropical and tropical coastlines of the world.

Method: Crown foliage dynamics of the mangrove Rhizophora stylosa were studies to reveal patterns of leaf recruitment, survival and seasonal leaf area growth.

Results: Flushing of leaves occurred throughout the year, but both flushing and leaf area growth pattern of leaves varied with season. Maximum flushing occurred in summer, but leaf areas did not differ significantly with season. The half-expansion period is longer, and the intrinsic rate of increase was lower in winter. Summer flushed leaves grew faster at their initial stage and reached their maximum area over a shorter period of time. The difference in temperature and air vapor pressure deficit (VPD) between summer and winter contributed to the present dynamics of foliage patterns. The mean leaf longevity was estimated to be 13.1 month. The crown foliage area was almost stable throughout the year.

Conclusions: Homeostatic control of the crown foliage area may be accompanied by the existence of ecophysiological mechanisms in $R$. stylosa. Integrating crown foliage dynamics into forest models represents an important step towards incorporating physiological mechanisms into the models for predicting growth responses to environmental changes and for understanding the complex responses of tree growth and litter production.
\end{abstract}

Keywords: Crown foliage area; Rhizophora stylosa; Leaf area growth; Leaf survivorship; Litterfall; Temperature

\section{Background}

Mangroves are woody plant communities that are almost exclusively tropical (Saenger 2002), with some outliers in subtropical latitudes, notably southern Florida (USA), South Africa, Victoria (Australia) and southern Japan (Tomlinson 1986). Mangroves have important ecological value due to their high productivity in the form of leaf litterfall. Studies of canopy foliage dynamics can inform

\footnotetext{
* Correspondence: mangrove_coral@yahoo.co.in

'Graduate School of Engineering and Science, University of the Ryukyus,

Okinawa 903-0213, Japan

${ }^{2}$ Department of Mechanical and Environmental Informatics, Tokyo Institute of Technology, O-okayama 2-12-1-W8-13, Meguro-ku, Tokyo 152-8552, Japan Full list of author information is available at the end of the article
}

estimates of forest productivity (Parker 1995; Osada et al. 2001). Appearance, expansion and duration of individual leaves are critical determinants of canopy growth and development. Leaf area expansion is one of the fundamental processes of plant growth (Terrys et al. 1983). Several studies on leaf area expansion of temperate angiosperms (Kozlowski and Clausen 1966) suggest variations based on the type of shoots and the environment to which they are exposed (Kozlowski 1971). The importance of leaf area in controlling the rate of growth of plant dry mass has long been appreciated (Gregory 1921). However, few field experiments have investigated the effects of environmental factors on leaf area expansion. In the markedly seasonal 
temperate and boreal forest biomes, trees of most species have leaf phonologies, life spans (if deciduous) and demographies synchronized with seasonal patterns. A similar linkage of tree species phenology with seasonality occurs in many, but not all, species in decidedly seasonal tropical forests and woodlands (Shukla and Ramakrishnan 1984; Reich et al. 1995; Williams et al. 1997). In contrast, in relatively small changes in seasonal environments, phenology, longevity and demography may be asynchronous within and among different species (Borchert 1980).

The phenological clarification of their life histories and developmental processes is helpful for understanding not only the dynamics of crowns, but also the productivity of forests. To monitor continuous changes in leaf areas and their subsequent growth, a modeling approach is essential. Leaf area growth and leaf survival are important factors that determine how plants will function. Leaf longevity may be considered a balance between lifetime carbon gain of a leaf and its construction and maintenance costs (Chabot and Hicks 1982; Reich et al. 1991). The balance between leaf loss due to litterfall and leaf gain as a factor in production is important in the maintenance of crown foliage dynamics, which regulate the primary productivity of mangrove forests. It is reported that light availability affects the life span of leaves directly via a plastic response (i.e., acclimation) (Ackerly and Bazzaz 1995; Miyaji et al. 1997) and indirectly via adaptation to the life span of trees (Coley 1988). This life span is an important historical trait of plants with respect to their growth and response to light, nutrient availability, drought, herbivory, air pollution and other factors (Monk 1966; Small 1972; Chapin 1980; Gray and Schlesinger 1983; Reich 1987; Coley 1988). On a larger scale, the life span of leaves is an important variable in comparing stand-level productivity, nutrient cycling and decomposition between evergreen and deciduous forests (e.g., Bray and Gorham 1964; Gosz 1981; Vogt et al. 1987; Sprugel 1989; Gower and Richards 1990). Nevertheless, few studies of these phenomena have been reported in mangrove species.

Mangroves on Okinawa are located in the subtropics, near the northern limit in latitude of these trees in East Asia, where mangrove communities cope with substantial seasonal changes in environmental conditions (Suwa et al. 2006, 2008; Hoque et al. 2010). Many studies have examined seasonal patterns of mangrove productivity and phenology in relation to environmental factors (WiumAndersen 1981; Duke et al. 1984; Slim et al. 1996; Wafar et al. 1997; Chen et al. 2009; Kamruzzaman et al. 2012a, b, c; Sharma et al. 2012a, b). Phenological observations on and estimations of vegetative development in mangroves, such as leaf recruitment and loss, take leaf turnover and leaf longevity into account (Gill and Tomlinson 1971; Wium-Andersen and Christensen 1978; Wium-Andersen
1981; Duke et al. 1984; Analuddin et al. 2009; Sharma et al. 2010).

We anticipate that climatic and environmental factors influence leaf area growth and production on Okinawa mangroves, and examined crown foliaged dynamics under the influence of marked seasonality. Thus, the objectives of this study were to investigate the dynamics of crown foliage of the mangrove species Rhizophora stylosa in terms of leaf recruitment, survival and area growth pattern, and to infer mechanisms involved in the maintenance of crown foliage dynamics.

\section{Methods}

\section{Study area and climate conditions}

The present study was conducted in a mangrove forest $\left(26^{\circ} 11^{\prime}-38^{\circ} 31^{\prime} \mathrm{N}\right.$ and $\left.54^{\circ} 33^{\prime}-127^{\circ} 40^{\prime} \mathrm{E}\right)$ of Manko Wetland, Okinawa Island, Japan (Figure 1). This wetland is an important area for migratory birds and has, since 1999, been registered as a RAMSAR site and, as well, designated as a special wildlife sanctuary by the Ministry of the Environment, Japan. Most of the wetland is a mudflat, which exposed at low tide. The average salinity of the study area is $2.96 \% \pm 0.23 \%$. The study site is $1.4 \mathrm{~m}$ above mean sea level and experiences tidal inundation during high tides. Mangrove forest distributed along the southern shore. The pioneer mangrove Kandelia obovata (S., L.) Yong is the dominant species in the study site, and there are a few closed canopy patches of Rhizophora stylosa Griff., Bruguiera gymnorrhiza and Excoecaria agallocha $\mathrm{L}$.

Figure 2 is a Walter-type climate diagram, representing mean monthly temperatures and rainfall (2000-2009) in the southern part of Okinawa Island. The mean monthly minimum and maximum temperatures, respectively, are $16.7^{\circ} \mathrm{C} \pm 0.3^{\circ} \mathrm{C}$ (mean $\pm \mathrm{SE}$ ) in January and $29.1^{\circ} \mathrm{C} \pm 0.2^{\circ} \mathrm{C}$ in July. The mean annual temperature is $23.3^{\circ} \mathrm{C} \pm 1.3^{\circ} \mathrm{C}$. The heat index was $219.8^{\circ} \mathrm{C} \pm 15.4^{\circ} \mathrm{C}$ month, within the range of $180^{\circ} \mathrm{C}$ to $240^{\circ} \mathrm{C}$ month of subtropical regions as defined by Kira (1991). The mean monthly rainfall is over $100 \mathrm{~mm}$ throughout the year except in January, which has $99.3 \mathrm{~mm} \pm 18.0 \mathrm{~mm}$ and December with $86.7 \mathrm{~mm} \pm 15.9 \mathrm{~mm}$ of rain per month. The mean annual rainfall is $2104.9 \mathrm{~mm} \pm 25.0 \mathrm{~mm}$. Typhoons with strong winds and rains frequently strike the island between July and October. During the study period from April 2008 to March 2009 the study site did not experience any significant rain or wind event which might have altered litterfall.

Figure 3 shows the change in the mean monthly air vapor pressure deficit, VPD $(=100 \times \mathrm{VP} / \mathrm{RH}-\mathrm{VP})$, where $\mathrm{VP}$ is the mean monthly vapor pressure $(\mathrm{hPa})$ and $\mathrm{RH}$ the mean monthly relative humidity (\%) during our study period. The highest VPD was $11.5 \mathrm{hPa}$ in July and the lowest 6.44 hPa in March. 


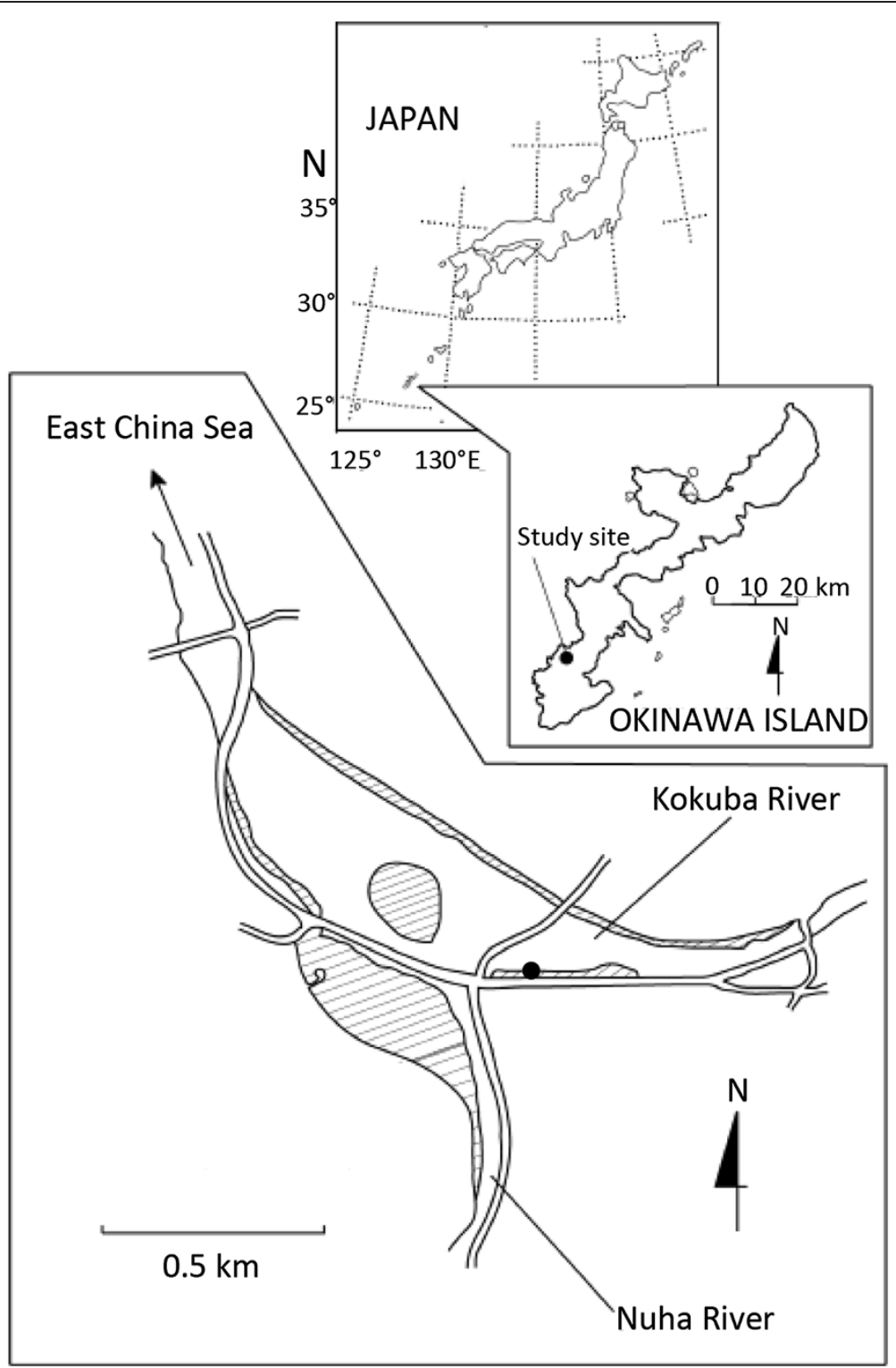

Figure 1 Location of study area. The hatched area indicates the mangrove area. The closed circle indicates the Rhizophora stylosa stand.

\section{Plot establishment, tree census and litterfall collection}

Five $4 \times 4 \mathrm{~m}$ plots were established in a specific monoculture $R$. stylosa stand, with a completely closed canopy. All individual trees in each of the plots were counted and numbered. Growth parameters, such as tree height $H$ and diameter at breast height (DBH) were measured in March 2008. Within each of the five plots two litterfall traps with a mouth area of $0.2 \mathrm{~m}^{2}$ each were placed $1 \mathrm{~m}$ above the soil surface in the $R$. stylosa stand. The litterfall traps were emptied monthly from April 2008 to March 2009, when we sorted the litterfall into leaves, stipules, flowers, propagules and branches. The litterfall was dried by sort to a constant mass at $80^{\circ} \mathrm{C}$ over a $48 \mathrm{~h}$ period and then weighed.

\section{Leaf recruitment, survival and growth}

As part of the tree census, a relatively tall tree with $H$ $4.32 \mathrm{~m}$ and $\mathrm{DBH} 5.46 \mathrm{~cm}$, was selected to observe leaf recruitment and survival (Figure 4). Infrastructure and manpower limitations restricted sampling to only one tree with 62 primary branches and 2674 leaves. Newly flushed leaves were labeled and counted each month. We obtained the total number of surviving and dying leaves on a monthly basis. The survival of leaves flushed each month was calculated by dividing the number of surviving leaves by the total number of leaves flushed during that month.

The leaf area growth process was tracked by randomly selecting 10 newly flushed leaves in each season. Their length and width were measured every three days until 


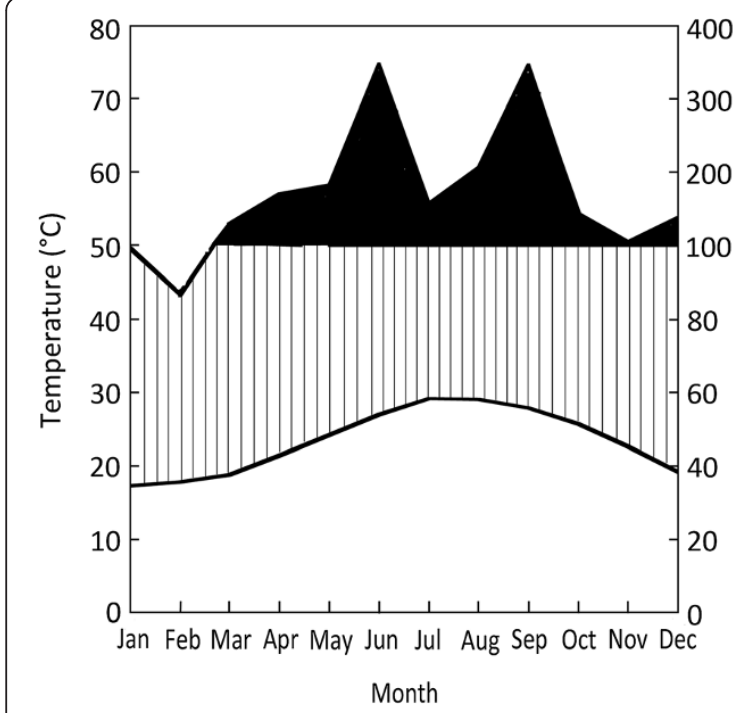

Figure 2 Walter-type climatic diagram for ten years (20002009). Mean annual temperature: $23.3^{\circ} \mathrm{C}$, mean annual rainfall: $2104.9 \mathrm{~mm} \cdot \mathrm{year}^{-1}$. The data were taken from the Okinawa Meteorological Observatory, Naha, Okinawa.

they reached their maximum. In order to develop a standard allometric equation, we measured leaf areas of the samples with an image scanner (Canon D2400U, Japan) and image analyzing software (Scion, Frederick, $\mathrm{Md})$. As shown in Figure 5, the following allometric

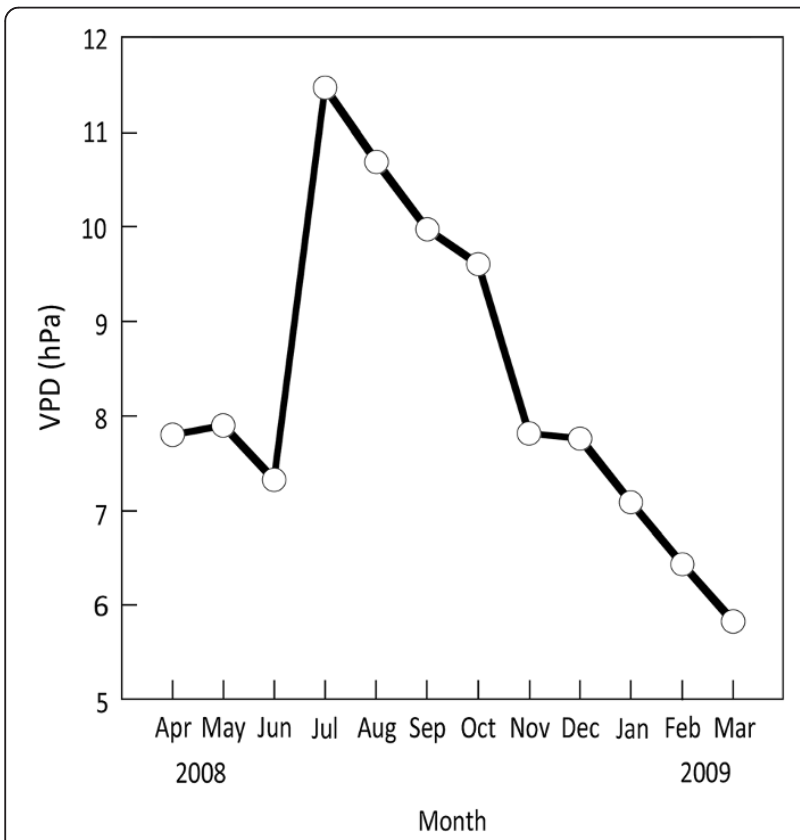

Figure 3 Seasonal changes in mean monthly air vapor pressure deficit (VPD) during the study period from April 2008 to March 2009. VPD values were calculated on the basis of the data taken from the Okinawa Meteorological Observatory, Naha, Okinawa.

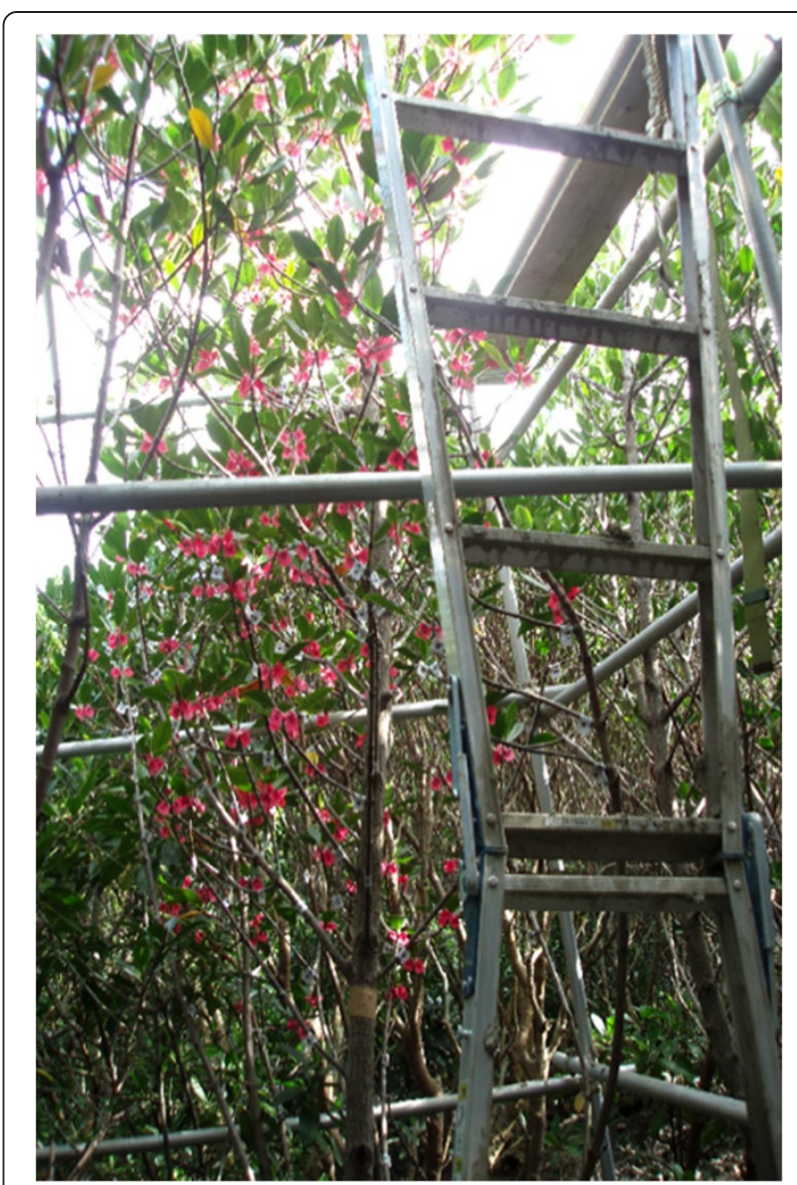

Figure 4 Profile of mangrove Rhizophora stylosa sample tree.

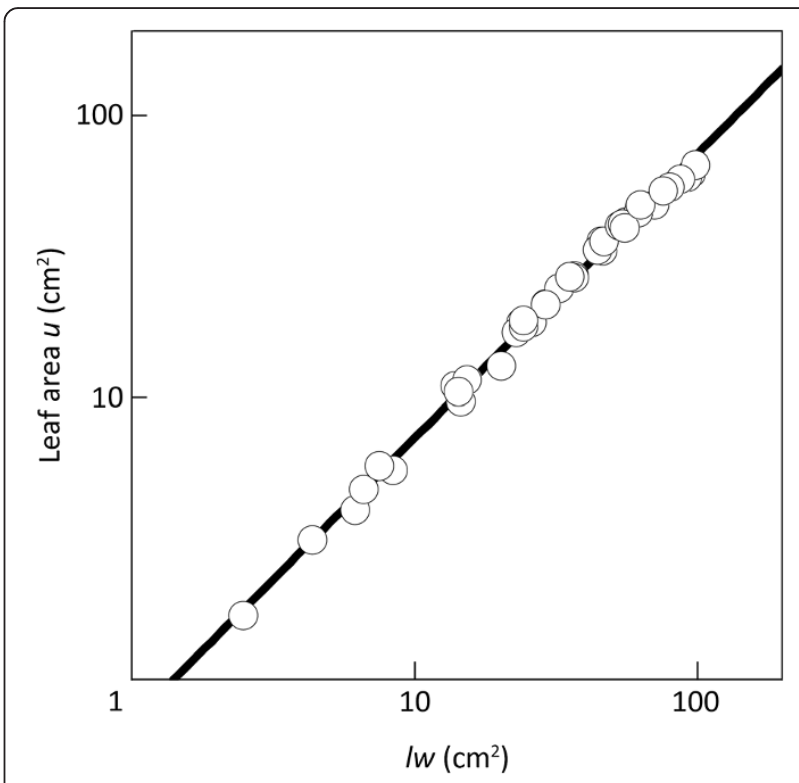

Figure 5 Allometric relationship of leaf area $u$ as a function of length $I$ and width $w$. Eq. (1) represents the straight line $\left(R^{2} \cong 1.0\right)$. 
relationship of leaf area $u\left(\mathrm{~cm}^{2}\right)$ as a function of leaf length $l(\mathrm{~cm})$ times width $w(\mathrm{~cm})$ was obtained:

$$
u=0.7201(l w)^{1.003}
$$

The area of surviving leaves was estimated using this allometric relationship.

The area of old leaves present at the beginning of April 2008 was estimated assuming that these old leaves flushed in different seasons and have already reached their maximum areas. Therefore, the total area of old leaves was calculated by multiplying the mean area of leaves by the number of old leaves remaining in each month. In addition, leaf recruitment and death were estimated indirectly on the basis of stipule litterfall (an indicator of newly flushed leaves) and leaf litterfall using litter traps.

\section{Seasonal changes in crown leaf area}

Crown leaf area $C(t)$ at any given month $t$ was calculated from the following equation (Analuddin et al. 2009):

$$
C(t)=\sum_{\tau=0}^{t} R_{\tau} \cdot S_{\tau}(t-\tau) \cdot u_{\tau}(t-\tau) \quad(t \geq \tau),
$$

where $N_{\tau}$ is the number of leaves flushed at any month $\tau$ before month $t, \mathrm{~S}_{\mathrm{T}}(\mathrm{t}-\mathrm{\tau})$ is the probability that the leaves will survive during period $t-\tau$ month and $\mathrm{u}_{\mathrm{T}}(\mathrm{t}-\mathrm{\tau})$ the mean leaf area of leaves just after a period of $t-\tau$ months.

\section{Data analyses}

A one-way ANOVA was performed to compare means and Tukey's HSD test was used for subsequent multiple comparisons using SPSS (Ver. 18.0 J, SPSS Inc., USA). The coefficients of our nonlinear equation were determined with the analytical statistical software KaleidaGraph (Ver. 4.1, Synergy Software, USA).

\section{Results}

\section{Stand structure, leaf recruitment and death}

Mean tree density, mean $H$ and mean DBH of the trees in the studied Rhizophora stylosa closed canopy stand were $2.26 \mathrm{~m}^{-2} \pm 0.14 \mathrm{~m}^{-2}$ (SE), $3.93 \mathrm{~m} \pm 0.72 \mathrm{~m}$ and $4.16 \mathrm{~cm} \pm 3.70 \mathrm{~cm}$, respectively. Seasonal changes in leaf recruitment and death, and in stipule and leaf litterfall are shown in Figure 6. The maximum stipule litterfall suggests that the flush of new leaves occurred in June (Figure 6A) and subsequently the maximum leaf recruitment was recorded in July (Figure 6B), while both maximum leaf litterfall (Figure 6A) and leaf death (Figure 6B) occurred in July. Leaf recruitment reached its minimum in January and stipule litterfall in February, while leaf death reached its minimum in December minimum leaf litterfall in
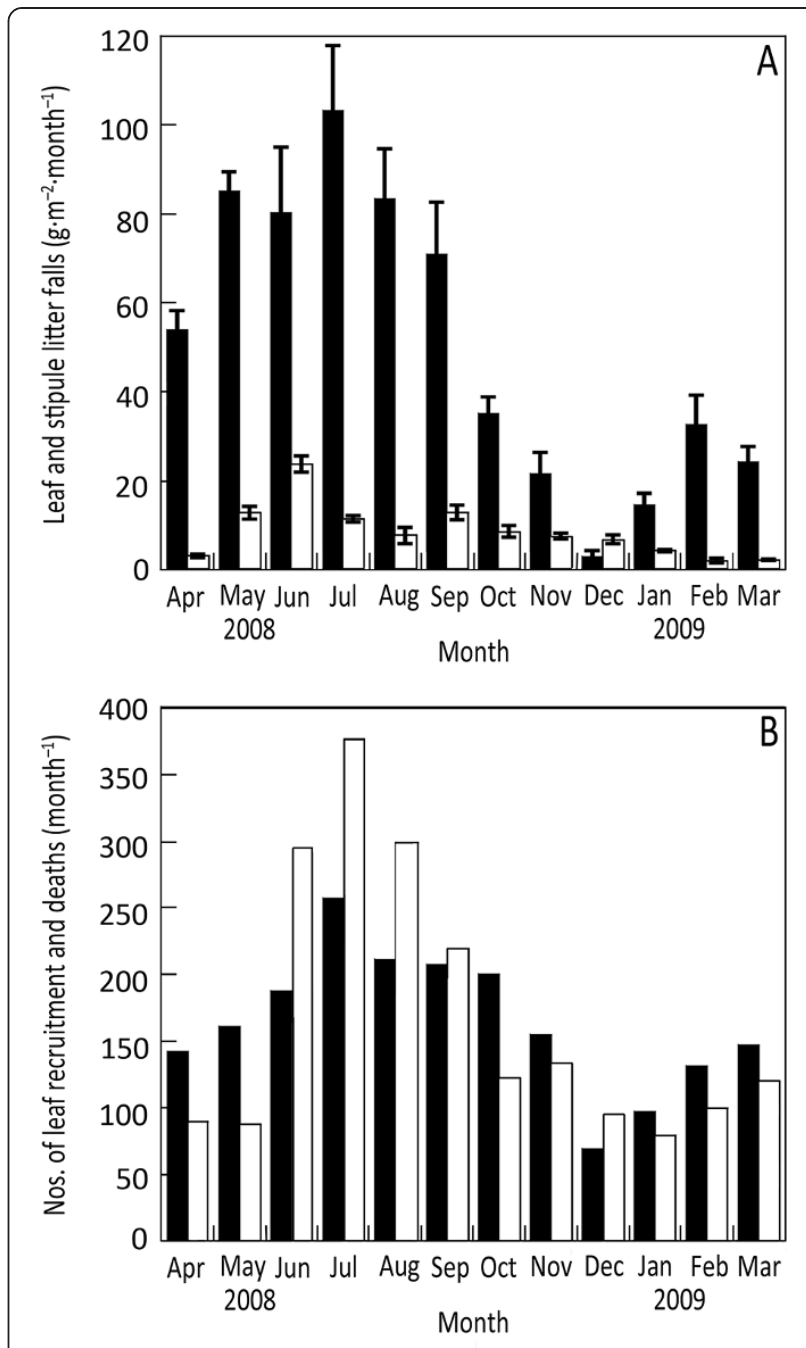

Figure 6 Seasonal variations in stipule (open columns) and leaf (closed columns) in the subplots $(A)$ and in leaf recruitment (open columns) and leaf death (closed columns) of a sample tree (B). Litter fall data are shown by mean \pm SE.

January. These results clearly suggest that these indirect measurements of seasonal patterns, i.e., stipule and leaf litterfall, are excellent and reliable of direct measurements, i.e., leaf recruitment and death.

\section{Leaf survival}

The monthly survival of leaves flushing during our experimental period is shown in Figure 7. The survival of new leaves most likely depends on the month when the leaves flush. As shown in the figure, it is clear that the survival, i.e., the probability that newly flushed leaves will survive during any given time interval, was lowest for leaves flushing in April to July and tended to increase thereafter. 


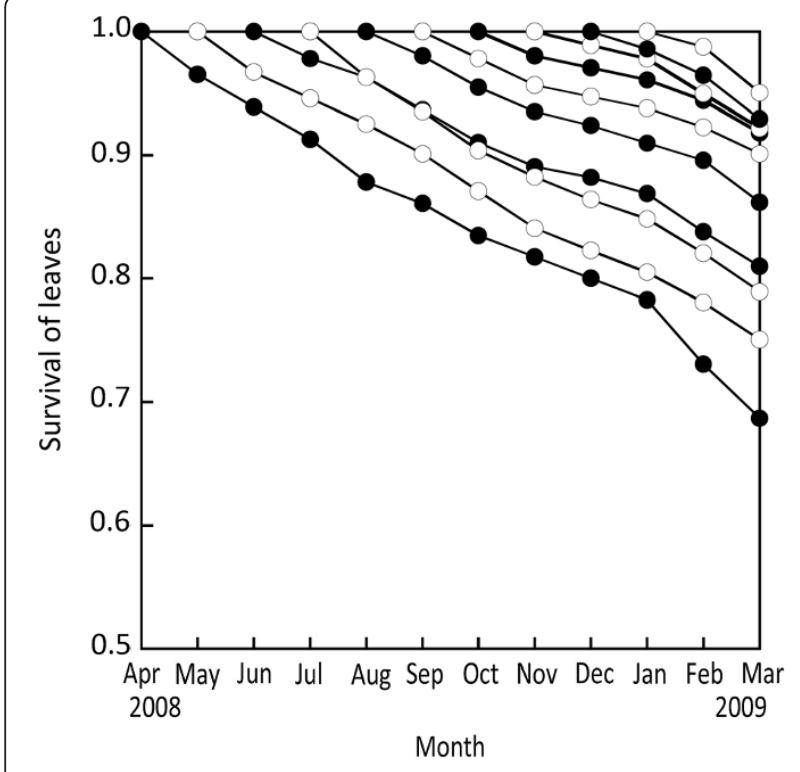

Figure 7 Monthly survival of flushed leaves.

\section{Leaf longevity}

Relative mortality rate (RMR), indicates the number of leaves dying per unit number of leaves alive at a time $t$ (Analuddin et al. 2009) as follows:

$$
\begin{aligned}
\mathrm{RMR} & =\lim _{\Delta \mathrm{t} \rightarrow 0} \frac{R \cdot\{S(t)-S(t+\Delta \mathrm{t})\}}{R \cdot S(t) \cdot \Delta \mathrm{t}} \\
& =-\frac{1}{S(t)} \frac{\mathrm{d} S(t)}{\mathrm{d} t}=-\frac{\mathrm{d} \ln S(t)}{\mathrm{d} t},
\end{aligned}
$$

where $R$ is the number of new leaves at time $t=0$ and their survival $S(t)(S(0)=1)$.

Therefore, the RMR during any period $\Delta t$ is calculated from the following equation:

$$
\mathrm{RMR} \cong \frac{\ln S(t)-\ln S(t+\Delta \mathrm{t})}{\Delta \mathrm{t}}
$$

The survival of the total number of leaves at the end of April 2008, i.e., at the start of the experiment, is shown Figure 8. It is apparent from this figure that the RMR is constant $(=\mu)$. Following Eq. (3), the survival $S(t)$ can be expressed in the form:

$$
S(t)=\mathrm{e}^{-\mu \cdot t}
$$

We estimated the constant $\mu$ to be 0.0766 month $^{-1}$.

On the other hand, the probability $L(t)$ that leaves die in month $t$ takes the form:

$$
L(t)=1-S(t)=1-\mathrm{e}^{-\mu \cdot t}
$$

Hence, the probability density function $l(t)$ of leaf longevity $t$ is derived as follows

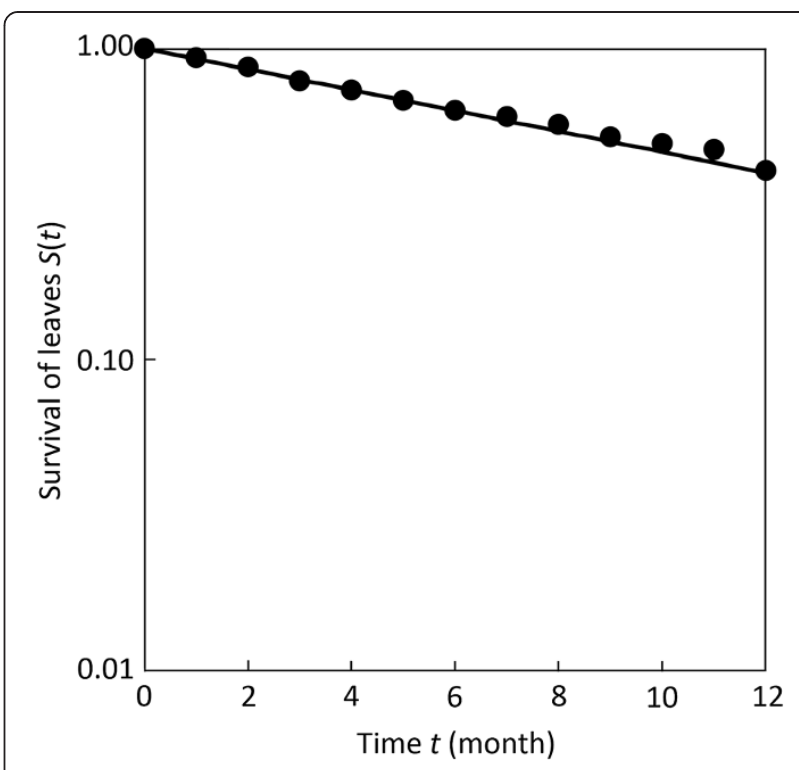

Figure 8 Survival $S(t)$ of the total number of leaves alive at the beginning of April 2008 over time $t\left(R^{2}=0.99\right)$.

$$
l(t)=\frac{\mathrm{d} L(t)}{\mathrm{d} t}=\mu \cdot \mathrm{e}^{-\mu \cdot t}
$$

As a result, mean leaf longevity $\mathrm{E}[t]$ is

$$
\mathrm{E}[t]=\int_{0}^{\infty} t \cdot l(t) \mathrm{d} t=\frac{1}{\mu}
$$

Therefore, the overall mean leaf longevity of our $R$. stylosa leaves was estimated to be 13.1 months.

\section{Seasonal patterns of leaf area growth}

The mean leaf area growth of leaves flushed in different seasons varied (Figure 9) with leaves flushing in winter taking a longer time (almost $90 \mathrm{~d}$ ) to reach their maximum leaf area size. On the other hand, leaves flushing in summer and autumn grow fast at the beginning to reach a point of inflection (around $30 \mathrm{~d}$ ) on the growth curve, gradually approaching a maximum by day 90 . Leaves flushing in the spring take almost 45 to $60 \mathrm{~d}$ to reach their inflection point on the growth curve. Although the growth of leaf area varies among leaves flushing in different seasons, the growing area of a single leaf $(u)$ can be formulated by the following logistic growth curve:

$$
\mathrm{u}=\frac{\mathrm{U}}{1+\mathrm{k} \cdot e^{-\lambda \cdot \mathrm{t}}}
$$

where $U$ is the maximum leaf area, $\lambda$ the intrinsic rate of increase and $k$ a constant. Assuming Eq. (9), the half-expansion period $t^{*}$, which is the time necessary 


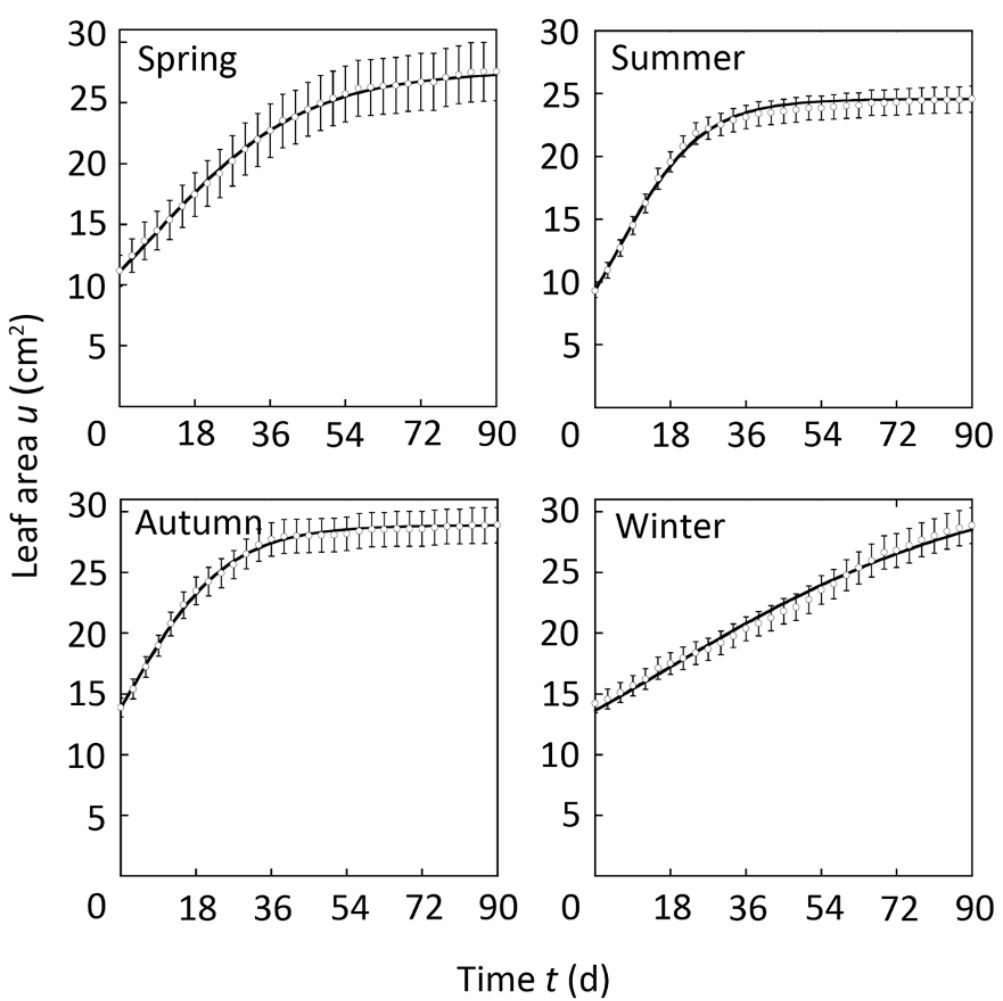

Figure 9 Area growth $\boldsymbol{u}$ of leaves over time $\boldsymbol{t}$ in different seasons. Eq. (9) represents our curves $\left(R^{2}=0.99\right)$. Data are shown with mean $\pm \mathrm{SE}$.

for a leaf area to reach one-half of its maximum, is defined as follows:

$$
t *=\frac{\ln \mathrm{k}}{\lambda}
$$

Equations 8 and 9 are used to express leaf area growth and half of the expansion period for two other mangrove species, i.e., Kandelia obovata (Analuddin et al. 2009) and Bruguiera gymnorhiza (Sharma et al. 2010). As shown in Figure 10, the half-expansion period $t^{\prime \prime}$ and intrinsic rate of increase $\lambda$ varied significantly among seasons, but the maximum leaf area $U$ remained fairly steady and did not show any significant difference among the seasons (Figure 10A). The $t^{\prime \prime}$ value was significantly longer in winter than the summer $(p=0.06)$ and autumn ( $p=0.002)$, while it did not show a significant difference with the spring season $(p=0.81)$ (Figure 10B). The $\lambda$ value of winter showed a significant difference with summer and spring $(p<0.0001)$ seasons, but the spring and autumn seasons did not show a significant difference $(p=0.14)$ (Figure 10C). It can therefore be concluded that leaves flushing in the summer grow initially faster and attain their maximum leaf area sooner than those flushing in winter.

\section{Seasonal changes in crown leaf area}

Crown leaf area $C(t)$ at any given month $t$ was calculated from Eq. (2), where $R_{T}$ is the number of leaves flushed at month $\tau$ before month $t$ (Figure 6A), $\mathrm{S}_{\mathrm{T}}(\mathrm{t}-\mathrm{\tau})$ the probability that the leaves will survive during any monthly period $t-\tau$ (Figure 7), and $\mathrm{u}_{\mathrm{T}}(\mathrm{t}-\mathrm{\tau})$ is the mean leaf area of the leaves just after the monthly period $t-\tau$ (Figure 9). Seasonal changes in crown leaf areas of our Rhizophora stylosa sample tree are illustrated in Figure 11, showing the fraction of crown leaf area of the old and new leaves in different months. The contribution of old leaves to crown area decreased progressively with crown growth as new leaves progressively contributed more than $80 \%$ of the total crown foliage area. The crown leaf area was almost stable over the year, with a mean value of $9.98 \mathrm{~m}^{2} \pm$ $0.17 \mathrm{~m}^{2}(\mathrm{SE})$, reaching a maximum of $10.63 \mathrm{~m}^{2}$ in October and a minimum of $8.65 \mathrm{~m}^{2}$ in April.

\section{Discussion}

Seasonal patterns of leaf recruitment (Figure 6A) in $R$. stylosa are highly correlated $(r=0.88, p<0.01)$ with those of stipule litterfall (Figure 6B), while seasonal patterns of leaf death (Figure 6A) in this species also correlated $(r=0.82, p<0.01)$ well with those of leaf litterfall (Figure 6B). In R. stylosa leaves that flushed in summer 


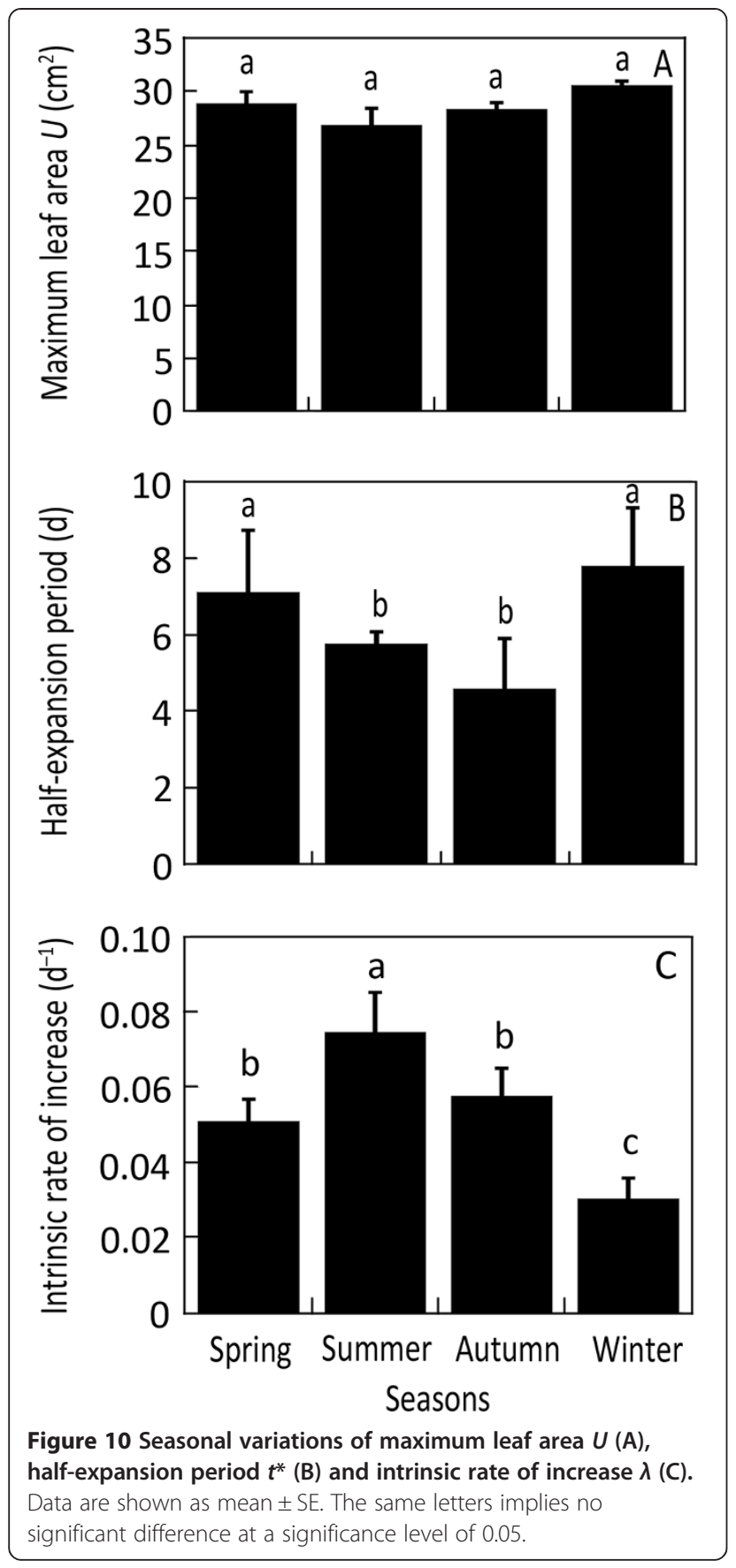

represented $38.1 \%$ of the annual total, whereas only $15.8 \%$ flushed in winter (Figure 6A). A similar seasonal trend in leaf recruitment in $K$. obovata was recorded (Gwada et al. 2000; Analuddin et al. 2009; Kamruzzaman et al. 2012a). Hardiwinoto et al. (1989) and Kamruzzaman et al. (2012c) also reported a similar seasonal trend in B. gymnorhiza, with the highest values in summer and the lowest in winter. Leaf recruitment and stipule litterfall of $R$. stylosa, B. gymnorhiza and K. obovata species on Okinawa are strongly correlated with the mean monthly air

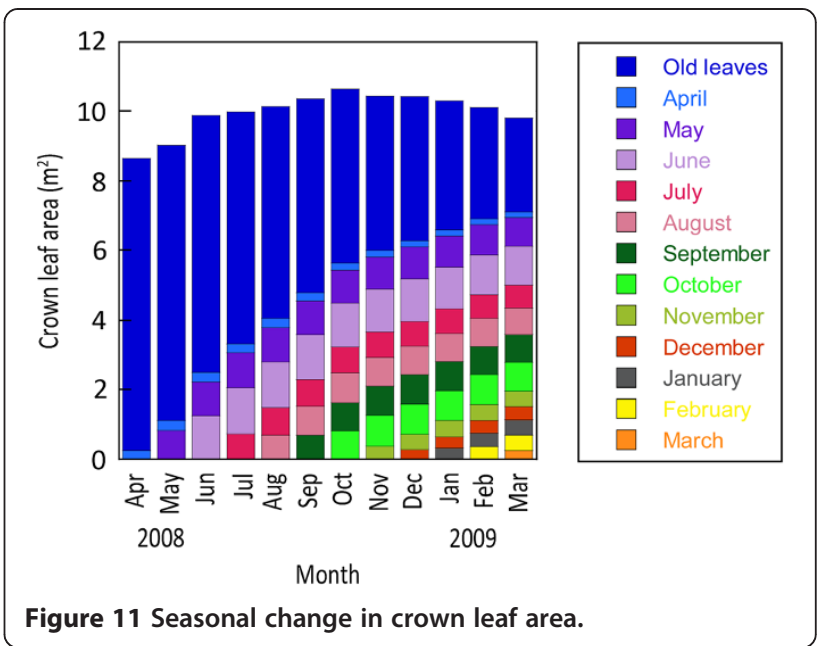

temperature and hours of sunshine (Sharma et al. 2012b). These results are also supported by Kamruzzaman et al. (2012a), who reported that leaf and stipule litterfall from $K$. obovata are highly correlated with monthly hours of sunshine and mean air temperature. All these observations are consistent with temperature-dependent seasonal growth in mangroves at the latitudinal limits (López-Portill and Ezcurra 1985; Saenger and Moverley 1985; Duke 1990). Wilson and Saintilan (2012) also found clear seasonal patterns in leaf production for mature R. stylosa in NSW, Australia. We measured the lowest leaf recruitment rates during winter, with progressive increases into summer (Figure 6A). These findings are congruent with those of Gill and Tomlinson (1971) and Parkinson et al. (1999), who reported that leaf fall and leaf production are low in subtropical regions during the winter season. Decreases in leaf production in winter may be caused by stresses induced by low temperatures.

In the present study the mean leaf longevity (direct method) of $R$. stylosa was 13.1 months (Figure 8). Sharma et al. (2012b) reported estimated mean leaf longevity for R. stylosa, B. gymnorhiza and K. obovata of 13.9, 17.2 and 12.1 months in the same study area using leaf mass and a leaf litterfall ratio (indirect method). Both direct and indirect methods are showing almost the same results for mean leaf longevity. Mangrove leaf longevity is probably linked to internal and external factors, such as salt concentration, changes in nutrient concentration, leaf mass and area and herbivory among others. Christensen and Wium-Andersen (1977) reported 18-month leaf longevity in Rhizophora apiculata Bl. growing in Thailand. Saenger (2002) also reported 18 months leaf longevity of the same species in Gladstone, northeastern Australia. Wilson and Saintilan (2012) reported a range of apparent minimum leaf life spans of 13 to more than 41 months for R. stylosa in NSW, Australia. According to Wang and Lin 
(1999), the life span of B. gymnorhiza leaves in China is approximately 9 or 10 months. Leaf longevity of seedlings of this species growing in gaps and closed canopies in Thailand is 1.53 and 1.41 years, respectively (Imai et al. 2009); these values in seedlings can be attributed to low rates of leaf loss and high levels of leaf production. Wright et al. (2004) recorded leaf longevity for as little as a few weeks for some herbaceous species and 20 years or more for some woody species. Kikuzawa and Lechowicz (2011) stated that leaf longevity of evergreen broadleaved trees in temperate regions is usually 1 to 5 years. The timing of leaf emergence and litterfall is associated with translocation of resources from senescence to emerging leaves (Nitta and Ohsawa 1997). Usually in response to freezing or draught stress, the deciduous habit is characterized by complete leaf shedding during unfavorable periods. Edwards and Grubb (1977) reported from New Guinea forests that leaf longevity of trees averaged only 1.4 years. Bentley (1979) reported trees in an understory with leaf longevity of more than two years. Hatta and Darnaedi (2005) reported from among nearly 100 species from Bogor and Chibotas, Indonesia (evergreen habit), that about half of these species have a leaf longevity of less than one year. They found in some shrubs, such as Inga edulis and Cryptocarya oblique, that leaf longevity was about two months and in Cinnamomum simtoc it was 30 months.

The growth pattern of leaves varied with seasons (Figure 9). The maximum leaf area was almost the same throughout the year (Figure 10A). Growth of an individual leaf can be separated into two distinct stages, the first of which is growth by cell division and the second by cell enlargement. Maximum leaf area is dependent upon position to a certain extent, but how far this is related to a similar dependence of leaf size with position in plants with a sequential production of leaves is an interesting point for further investigation. Leaf growth patterns are known to be affected by various environmental factors, such as temperature, water availability, irradiance, mineral nutrition and $\mathrm{CO}_{2}$ concentration. Clifton-Brown and Jones (1999) concluded that the effects of VPD on leaf extension observed in Miscanthus can be largely attributed to changes in the rate of transpiration and leaf water status, if temperatures are close to the threshold for growth. Where VPD effects are found to be transient, it is anticipated that models relating leaf growth only with temperature (Clifton-Brown and Jones, 1997) are adequate for the prediction of leaf area development of Miscanthus $\times$ giganteus in the range of temperature conditions between $6^{\circ} \mathrm{C}$ and $20^{\circ} \mathrm{C}$.

The half-expansion period (Figure 10B) and the intrinsic rate of increase (Figure 10C) were respectively longer and lower in the winter than in the other seasons, because the leaves of $R$. stylosa already grew inside the bud. Leaves flushed during the seasons other than winter grew faster initially and attained their maximum leaf area sooner than those flushed in winter. This may be due to the differences in temperature and VPD between winter and the other seasons (Figure 2). Beadle (1997) suggested that, when water and nutrient supplies are adequate, a major variable determining growth is air temperature above a minimum critical temperature. The combined effect of high leaf temperature and VPD could induce an increase in transpiration rate in order to maintain a favorable leaf temperature through evaporative cooling (Youssef and Saenger 1998). High air temperature and VPD had a detrimental effect on leaf elongation of a sorghum cultivar (Lafarge and Tardieu 2002). Thus, for reducing the environmental stresses of high temperature and VPD in the summer the shorter half-expansion period of summer leaves is probably essential. On the other hand, lower temperature and VPD in the winter may prolong the half-expansion period of winter leaves. The larger area of winter leaves may compensate for their amount of carbon uptake, which is lower in the winter. Leaf area can enhance the opportunity for carbon uptake, albeit at the cost of a greater demand for water (Ferris et al. 2001). Tall red mangrove forests in the Florida Everglades exhibit dynamic carbon assimilation patterns strongly modulated by the prevailing atmospheric conditions and the physiological responses to the local climate (Barr et al. 2009).

In contrast to the seasonal fluctuation of leaf area growth, crown leaf areas were almost stable throughout the year (Figure 11), as if homeostatic control is likely to function, although leaves composing the crown showed a seasonally dependent growth pattern. Equation (2) states that crown leaf area $C(t)$ is determined by leaf recruitment $N_{\tau}$, leaf death $\mathrm{S}_{\mathrm{\tau}}(\mathrm{t}-\tau)$ and leaf area growth $\mathrm{u}_{\mathrm{\tau}}(\mathrm{t}-\mathrm{\tau})$. The present result suggests that newly flushed leaves and their area growth contribute to an increase in crown leaf area. This crown leaf area gradually increased from April to October because the number of leaves recruitment was much higher than that of leaves dying in the same period.

Furthermore, the homeostatic control of crown leaf areas may also be accompanied by the regulation of leaf recruitment and reproduction. Rhizophora stylosa and $K$. obovata exhibited a decreasing tendency in new leaf production, when the production of reproductive organs was at a maximum (Kamruzzaman et al. 2012b). Sharma et al. (2012a) also reported the same trend for K. obovata mangroves in subtropical regions. This may be because the production of flowers and propagules imposes a heavy burden on leaf recruitment. Decreases in stipule litterfall, or newly flushed leaves, with increasing flower and propagule litterfall are not only caused by the fluctuations of environmental factors, but may be mainly due to the partitioning of resources for flower production and the growth 
of propagules. Therefore, the present results suggest the existence of integrated eco-physiological mechanisms between internal and external factors that maintain the crown leaf area of $R$. stylosa.

\section{Conclusions}

Our results corroborate the postulate that leaf production and leaf death of the mangrove species $R$. stylosa vary seasonally. An overall estimated mean leaf longevity was 13.1 months, which is almost the same as that estimated using an indirect method. The growth patterns of leaves varied among seasons with crown leaf areas increasing gradually from April to October when recruitment of new leaves exceeds the death rate. The crown leaf areas decreased during November when recruitment of new leaves was smaller than that of leaves dying. Decreases in crown leaf area may be important for minimizing the demand for water in the face of higher temperatures and VPD. These results suggest that $R$. stylosa has a mechanism to maintain an efficient crown in response to seasonal changes in environmental factors.

\section{Competing interests}

The authors declare that they have no competing interests.

\section{Authors' contributions}

SS and AH designed the study. SS, ATMRH and KA carried out the field work, data collection and preparation of them. SS did the data analysis and updation of the article. SS and ATMRH edited the final version of the MS. Al authors read and approved the final manuscript.

\section{Acknowledgements}

We are grateful to our colleagues, Drs. S.M. Feroz, W. Min and R. Deshar, for their cooperation and active participation in the field work. We also thank anonymous reviewers for their suggestions and useful guidance on our manuscript. This study was financed in part by a Grant-in-Aid for Scientific Research (No. 23380094) from the Ministry of Education, Culture, Sports, Science and Technology, Japan.

\section{Author details \\ ${ }^{1}$ Graduate School of Engineering and Science, University of the Ryukyus, Okinawa 903-0213, Japan. ${ }^{2}$ Department of Mechanical and Environmental Informatics, Tokyo Institute of Technology, O-okayama 2-12-1-W8-13, Meguro-ku, Tokyo 152-8552, Japan. ${ }^{3}$ Institute of Forestry and Environmental Sciences, Chittagong University, Chittagong 4331, Bangladesh. ${ }^{4}$ Department of Biology, Haluoleo University, Kendari 93232, Indonesia. ${ }^{5}$ Laboratory of Ecology and Systematics, Faculty of Science, University of the Ryukyus, Okinawa 903-0213, Japan.}

Received: 1 April 2014 Accepted: 18 July 2014

Published: 12 August 2014

\section{References}

Ackerly DD, Bazzaz FA (1995) Leaf dynamics, self-shading and carbon gain in seedlings of a tropical pioneer tree. Oecologia 101:289-298

Analuddin K, Sharma S, Suwa R, Hagihara A (2009) Crown foliage dynamics of mangrove Kandelia obovata in Manko Wetland, Okinawa Island, Japan. J Oceanogr 65:121-127

Barr JG, Fuentes JD, Engel V, Zieman JC (2009) Physiological responses of red mangroves to the climate in the Florida Everglades. J Geophys Res 114:1-13

Beadle CL (1997) Dynamics of leaf and canopy development. In: Nambiar EKS, Brown A (eds) Management of Soil, Water and Nutrients in Tropical Plantation Forests, Canberra., pp 169-212

Bentley BL (1979) Longevity of individual leaves in a tropical rainforest understory. Ann Bot 43(1):119-121
Borchert R (1980) Phenology and ecophysiology of tropical trees: Erythrinapoeppigiana O. F Cook Ecology 61:1065-1074

Bray JR, Gorham E (1964) Litter production in forests of the world. Adv Ecol Res 2:101-157

Chabot BF, Hicks DJ (1982) The ecology of leaf life spans. Ann Rev Ecol Sys 13:229-259

Chapin FS (1980) The mineral nutrition of wild plants. Ann Rev Ecol Syst 11:233-260

Chen L, Zan Q, Li M, Shen J, Liao W (2009) Litter dynamics and forest structure of the introduced Sonneratia caseolaris mangrove forest in Shenzhen, China. Estuar Coast Shelf Sci 85:241-246

Christensen B, Wium-Andersen S (1977) Seasonal growth of mangrove trees in Southern Thailand. I. The phenology of Rhizophora apiculata BI. Aquat Bot 3:271-276

Clifton-Brown JC, Jones MB (1997) The thermal response of leaf extension rate in genotype of the C4-grass Miscanthus: an important factor in determining the potential productivity of different genotype. J Exp Bot 48:1573-1581

Clifton-Brown JC, Jones MB (1999) Alteration in transpiration rate, by changing air vapour pressure deficit, influences leaf extension rate transiently in Miscanthus. J Exp Bot 50:1393-1401

Coley PD (1988) Effects of plant growth rate and leaf lifetime on the amount and type of anti-herbivore defense. Oecologia 74:531-536

Duke NC (1990) Phenological trends with latitude in the mangrove tree Avicennia marine. J Ecol 78:113-133

Duke NC, Bunt JS, Williams WT (1984) Observations of the floral and vegetative phenologies of north-eastern Australian mangroves. Aust J Bot 32:87-99

Edwards PJ, Grubb PJ (1977) Studies of mineral cycling in a montane rain forest in New Guinea. I. The distribution of organic matter in the vegetation and soil. J Ecol 65:943-969

Ferris R, Sabatti M, Miglietta F, Mills RF, Taylor G (2001) Leaf area is stimulated in Populus by free air $\mathrm{CO}_{2}$ enrichment (POPFACE), through increased cell expansion and production. Plant Cell Environ 24:305-315

Gill AM, Tomlinson PB (1971) Studies on the growth of red mangrove (Rhizophora mangle L.). 3. Phenology of the shoot. Biotropica 3:109-124

Gosz JR (1981) Nitrogen cycling in coniferous ecosystems. In: Clark FE, Rosswall (eds) Terrestrial Nitrogen Cycles, vol 33. Ecol Bull, Stockholm, pp 405-426

Gower ST, Richards JH (1990) Larches: deciduous conifers in an evergreen world. Bioscience 40:818-826

Gray JT, Schlesinger WH (1983) Nutrient use by evergreen and deciduous shrubs in Southern California. II. Experimental investigations of the relationships between growth, nitrogen uptake and nitrogen availability. J Ecol 71:43-56

Gregory FG (1921) Studies in the energy relations of plants. I. The increase in area and leaf surface of Cucumissativus. Ann Bot 35:93-123

Gwada P, Tsuchiya M, Uezu Y (2000) Leaf phenological traits in the mangrove Kandelia candel (L.) Druce. Aquat Bot 68:1-14

Hardiwinoto S, Nakasuga T, Igarashi T (1989) Litter production and decomposition of mangrove forest at Ohura Bay, Okinawa. Res Bull Coll Exper Forests Hokkaido Univ 46:577-594

Hatta H, Darnaedi D (2005) Phenology and growth habits of tropical trees. National Science Museum, Tsukuba, p 439

Hoque ATMR, Sharma S, Suwa R, Hagihara A (2010) Seasonal variation in the size-dependent respiration of mangroves Kandelia obovata. Mar Ecol-Prog Ser 404:31-37

Imai N, Takyu M, Nakamura Y (2009) Growth, crown architecture and leaf dynamics of saplings of five mangrove tree species in Ranong, Thailand. Mar Ecol-Prog Ser 377:139-148

Kamruzzaman M, Sharma S, Hagihara A (2012a) Vegetative and reproductive phenology of the mangrove Kandelia obovata. Plant Spec Biol 28(2):118-129

Kamruzzaman M, Sharma S, Hoque ATMR, Hagihara A (2012b) Litter fall of three subtropical mangrove species in the family Rhizophoraceae. J Oceanogr 68:841-850

Kamruzzaman M, Sharma S, Mouctar M, Hagihara A (2012c) Vegetative and reproductive phenology of the mangrove Bruguiera gymnorrhiza (L.) Lamk Trees-Struct Funct 27(3):619-628

Kikuzawa K, Lechowicz MJ (2011) Ecology of leaf longevity. Ecological Research Monographs. Springer, Tokyo, p 145

Kira T (1991) Forest ecosystems of east and southeast Asia in a global perspective. Ecol Res 6:185-200

Kozlowski T (1971) Growth and development of trees. Academic, New York

Kozlowski TT, Clausen JJ (1966) Shoot growth characteristics of heterophyllous woody plants. Can J Bot 44:827-843 
Lafarge T, Tardieu F (2002) A model coordinating the elongation of all leaves of a sorghum cultivar was applied to both Mediterranean and Sahelian conditions. J Exp Bot 53:715-725

López-Portill J, Ezcurra E (1985) Litterfall of Avicennia germinans L. in a oneyear cycle in a mudflat at the Mecoacán Lagoon, Tabasco, México. Biotropica 17:186-190

Miyaji K, Silva WS, Alvim PT (1997) Productivity of leaves of a tropical tree, Theobroma cacao, grown under shading, in relation to leaf age and light conditions within the canopy. New Phytol 137:463-472

Monk CD (1966) An ecological significance of evergreenness. Ecology 47:504-505

Nitta I, Ohsawa M (1997) Leaf dynamics and shoot phenology of eleven warm-temperate evergreen broad-leaved trees near their northern limit in central Japan. Plant Ecol 130:71-88

Osada N, Takeda H, Furukawa A, Awang M (2001) Leaf dynamics and maintenance of tree crowns in a Malaysian rain forest stand. J Ecol 89:774-782

Parker GG (1995) Structure and microclimate of forest canopies. In: Lowman MD, Nadkarni NM (eds) Forest Canopies. Academic, California, pp 73-106

Parkinson RW, Perez-Bedmar M, Santangelo JA (1999) Red mangrove (Rhizophora mangle L.) litter fall response to selective pruning (Indian River Lagoon, Florida, U.S.A.). Hydrobiologia 413:63-76

Reich PB (1987) Quantifying plant response to ozone: a unifying theory. Tree Physiol 3:347-360

Reich PB, Uhl C, Walters MB, Ellsworth DS (1991) Leaf lifespan as a determinant of leaf structure and function among 23 trees species in Amazonian forest communities. Oecologia 86:16-24

Reich PB, Ellsworth DS, Uhl C (1995) Leaf carbon and nutrient assimilation and conservation in species of differing successional status in an oligotrophic Amazonian forest. Funct Ecol 9:65-76

Saenger P (2002) Mangrove Ecology. Silviculture and Conservation, Kluwer, Dordrecht

Saenger P, Moverley J (1985) Vegetative phenology of mangroves along the Queensland coastline. Proc Ecol Soc Aust 13:257-265

Sharma S, Hoque ATMR, Analuddin K, Hagihara A (2010) Seasonal foliage dynamics of mangrove Bruguiera gymnorrhiza (L.) Lamk. In a subtropical region, Manko Wetland, Okinawa Island, Japan. Proc. of the 15th Int. Forestry and Environment Symposium: 26-27 Nov. 2010. Dept. of For. \& Env. Sci., Univ. of Jayewardenepura, Sri Lanka, pp 237-244

Sharma S, Hoque ATMR, Analuddin K, Hagihara A (2012a) Litterfall dynamics in an overcrowded mangrove Kandelia obovata (S., L.) Yong stand over five years. Estuar Coast Shelf Sci 98:31-41

Sharma S, Hoque ATMR, Kamruzzaman M, Hagihara A (2012b) Leaf phenological traits and longevity in three mangrove species (Rhizophoraceae) on Okinawa, Japan. J Oceanogr 68:831-840

Shukla RP, Ramakrishnan PS (1984) Leaf dynamics of tropical trees related to successional status. New Phytol 97:697-706

Slim FJ, Gwada PM, Kodjo M, Hemminga MA (1996) Biomass and litterfall of Ceriopstagal and Rhizophora mucronata in the mangrove forest of Gazi Bay, Kenya. Mar Freshw Res 47:999-1007

Small E (1972) Photosynthetic rates in relation to nutrient recycling as an adaptation to nutrient deficiency in peat bog plants. Can J Bot 50:2227-2233

Sprugel DG (1989) The relationship of evergreenness, crown architecture and leaf size. Am Nat 133:464-479

Suwa R, Hagihara A (2008) Seasonal changes in canopy photosynthesis and foliage respiration in a Rhizophora stylosa stand at the northern limit of its natural distribution. Wetl Ecol Manag 16:313-321

Suwa R, Khan MNI, Hagihara A (2006) Canopy photosynthesis, canopy respiration and surplus production in a subtropical mangrove Kandelia candel forest, Okinawa Island, Japan. Mar Ecol Prog Ser 320:131-139

Terrys N, Waldron LJ, Taylor SE (1983) Environmental influence on leaf expansion. In: Dalke JE, Milthorpe FL (eds) The Growth and Functioning of Leaves. Cambridge University Press, Cambridge, pp 179-205

Tomlinson PB (1986) The Botany of Mangroves. Cambridge University Press, Cambridge

Vogt T, Prosch P, Gülz PG (1987) Epicuticular flavonoid aglycones in the genus Cistus, Cistaceae. J Plant Physiol 131:25-36

Wafar S, Untawale AG, Wafar M (1997) Litter fall and energy flux in a mangrove ecosystem. Estuar Coast Shelf Sci 44:111-124

Wang WQ, Lin P (1999) Transfer of salt and nutrients in Bruguiera gymnorrhiza leaves during development and senescence. Mangroves Salt Marshes 3:1-7

Williams RJ, Myers BA, Muller WJ, Duff GA, Eamus D (1997) Leaf phenology of woody species in a north Australian tropical savanna. Ecology 78:2542-2558
Wilson NC, Saintilan N (2012) Growth of the mangrove species Rhizophora stylosa Griff. at its southern latitudinal limit in eastern Australia. Aquat Bot 101:8-17

Wium-Andersen S (1981) Seasonal growth of mangrove trees in southern Thailand. III. Phenology of Rhizophora mucronata Lamk. and Scyphiphora hydrophyllacea aertn. Aquat Bot 10:371-376

Wium-Andersen S, Christensen B (1978) Seasonal growth of mangrove trees in southern Thailand. II. Phenology of Bruguiera cylindrical, Ceriops tagal, Lumnitzera littorea and Avicennia marina. Aquat Bot 5:383-390

Wright IJ, Reich PB, Westoby M, Ackerly DD, Baruch Z, Bongers F, Cavender-Bares J, Chapin T, Cornelissen JH, Diemer M, Flexas J, Garnier E, Groom PK, Gulias J, Hikosaka K, Lamont BB, Lee T, Lee W, Lusk C, Midgley JJ, Navas ML, Niinemets U, Oleksyn J, Osada N, Poorter H, Poot P, Prior L, Pyankov VI, Roumet C, Thomas SC et al (2004) The worldwide leaf economics spectrum. Nature 428(6985):821-827

Youssef T, Saenger P (1998) Photosynthetic gas exchange and water use in tropical and subtropical populations of the mangrove Aegiceras corniculatum. Mar Freshw Res 49:329-334

\section{doi:10.1186/s40663-014-0015-2}

Cite this article as: Sharma et al: A model of seasonal foliage dynamics of the subtropical mangrove species Rhizophora stylosa Griff. growing at the northern limit of its distribution. Forest Ecosystems 2014 1:15.

\section{Submit your manuscript to a SpringerOpen ${ }^{\odot}$ journal and benefit from:}

- Convenient online submission

- Rigorous peer review

- Immediate publication on acceptance

- Open access: articles freely available online

- High visibility within the field

- Retaining the copyright to your article

Submit your next manuscript at $>$ springeropen.com 